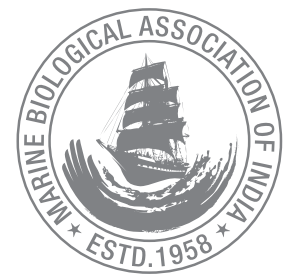

\title{
Fifteen new records of Batoids (Elasmobranchii) from waters off Andaman and Nicobar Islands, India
}

\author{
K. K. Bineesh'*, R. R. Kumar', S. Venu', M. Nashad², V. S. Basheer ${ }^{3}$, K. V. Akhilesh ${ }^{4}$ \\ and C. Sivaperuman \\ Andaman and Nicobar Regional Centre, Zoological Survey of India, Port Blair - 744102, Andaman Islands, India. \\ 'Department of Ocean Studies and Marine Biology, Pondicherry University, Port Blair Campus - 744 112, Andaman \\ Islands, India. \\ ${ }^{2}$ Fishery Survey of India, Zonal Base, Port Blair - 744 101, Andaman and Nicobar Islands, India \\ ${ }^{3}$ The Peninsular and Marine Fish Genetic Resources (PMFGR) Centre, ICAR-NBFGR Cochin Centre, Kerala, India. \\ ${ }^{4}$ Research Centre of ICAR-Central Marine Fisheries Research Institute, Mumbai, 400 061, Maharashtra, India. \\ *Correspondence e-mail: kkbineesh@gmail.com
}

Received: 20 July 2019 Accepted: 11 May 2020 Published: 25 May 2020

Original Article

\begin{abstract}
Marine waters of Andaman and Nicobar Islands, India in the tropical Indian Ocean, is a poorly explored high faunal diverse region. The present study documents new records of batoids from the region, identified during the fishery and diversity monitoring surveys conducted during November 2016 to June 2019 at different fish landing centers of Andaman and Nicobar Islands. Fifteen elasmobranch species including 2 wedgefishes, 1 skate and 12 rays were identified and confirmed as new reports for the region. Results of this study indicate that the elasmobranch diversity, especially batoid diversity of Andaman and Nicobar Islands are poorly documented and future systematic surveys including that of deeper reef habitat may help to explore the diversity in the region.
\end{abstract}

Keywords: Batoids, new records, bycatch, Andaman Nicobar Islands, India, Eastern Indian Ocean

\section{Introduction}

The Andaman and Nicobar group of Islands, India consists of 572 islands, islets and rocky outcrops located between $14^{\circ} \mathrm{N}$ and $6.5^{\circ} \mathrm{N}$ latitude in the south-eastern part of the Bay of Bengal in the northern Indian Ocean, occupying an area of $47,000 \mathrm{sq} . \mathrm{km}$. The islands are fragmented by straits and channels of varying widths and depths. (www.andaman.gov.in)

In India, elasmobranchs are landed as target or bycatch in commercial, artisanal and recreational fishing activities. For several years, India has been designated as a major elasmobranch fishing nation (Kizhakudan et al., 2015). However, the catch data reported by national marine fisheries monitoring agency ICAR-CMFRI in the last few decades does not include much information on the fisheries/diversity of elasmobranchs from the Andaman \& Nicobar Islands, after the closure of the CMFRI station in Andaman. The distance from mainland India ( $\sim 1370$ $\mathrm{km})$, lack of dedicated surveys and presence of targeted fishery for elasmobranchs make the Andaman and Nicobar Islands a must-study region for elasmobranch fishery and diversity.

The recent marine fish faunal studies from the Islands (Kumar et al., 2015, 2016, 2018; Pradeep et al., 2016, 2017, 2018; Vinu et al., 2017; Shirke et al., 2017; Tyabji et al., 2018) 


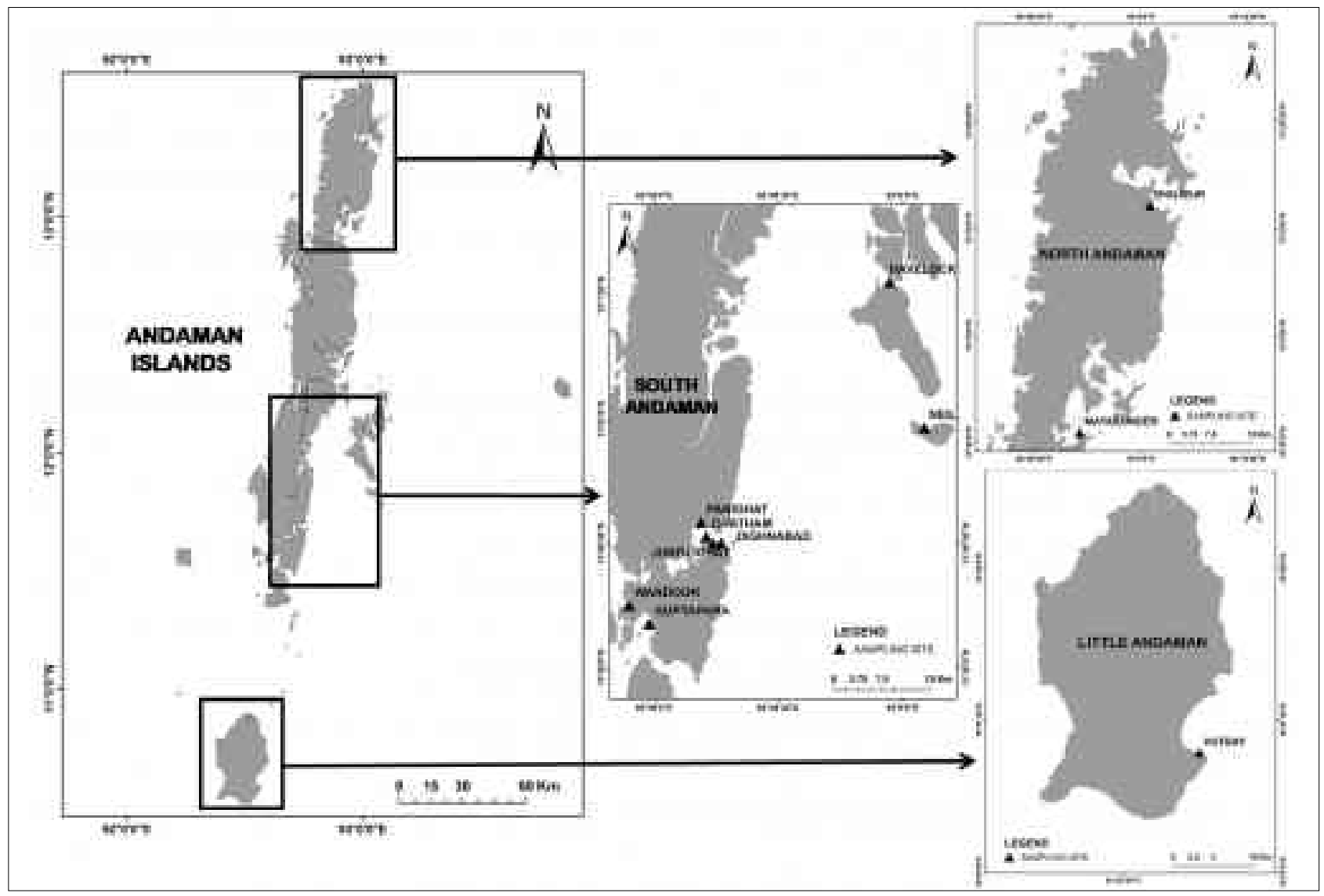

Fig. 1. Map showing the collection/observation locality

recorded higher diversity in the landings and exploratory surveys. These studies will support future fisheries management in the Islands and improve India's compliance to Convention of Biodiversity (CBD) in documenting its fauna. The present study was undertaken as a focused study on elasmobranch diversity from the region, and several species of batoids were identified as new distributional records. The diagnostic characteristics of these species are presented along with their photographs.

\section{Material and methods}

Weekly landing center/market surveys were conducted in Andaman and Nicobar Islands from November 2016 to June 2019 (Fig. 1). Samples collected and photographed during the exploratory survey of FORV Sagar Sampada in the waters off AN Islands, India (cruise no: 334 ) are also included in the present study. Species identification was carried out based on Last et al. (2016).

\section{Results and discussion}

During the present survey, 15 species of batoids were recorded which have not been previously reported from the Andaman and Nicobar Islands.

\section{Systematics}

Order: Rhinopristiformes

Family: Rhinidae

Rhynchobatus australiae Whitley, 1939

Bottlenose wedgefish (Fig. 2A)

Observation/materials: A single male specimen about $165 \mathrm{~cm}$ total length was caught as bycatch by motorized boat operated off North Sentinel Islands at 50 to $100 \mathrm{~m}$ depth and landed at Junglighat fish landing center, Port Blair on $9^{\text {th }}$ January 2019. The specimen is not retained.

Diagnosis: $R$. australiae can be differentiated from other wedgefish species by its bottle-shaped snout, small thorns on the back and around the eyes. Dorsal surface pale grey and sparse white spots, pectoral region hind margin surrounded by multiple small white spots, three in a line above black spot. First dorsal fin origin slightly behind the pelvic fin origin, the first dorsal fin is larger than the second dorsal fin (Last et al., 2016).

Remarks: Previously a single species Rhynchobatus djiddensis (Forsskål, 1775) was listed by Rao, 2003 from Andaman waters, 
which is questionable. The present study confirms the occurrence of $R$. australiae in Andaman waters and are occasionally landed as bycatch. At present quantitative abundance data is not available for $R$. australiae or any other batoids from this region, which is traded and consumed locally. The IUCN Red List of Threatened Species lists the status of $R$. australiae as Critically Endangered due to population declines and fishing pressure in the known range (Kyne et al., 2019).

Order: Rhinopristiformes

Family: Glaucostegidae

Glaucostegus typus (Anonymous [Bennett], 1830)

Giant shovelnose ray (Fig. 2B)

Observation/materials: A single mature male specimen G. typus measuring $195 \mathrm{~cm}$ total length was caught in motorized boat and landed at Junglighat fish landing center on $28^{\text {th }}$ December 2017. The specimen is not retained.

Diagnosis: G. typus is a large batoid with a flattened, spade to wedge-shaped disc. Pelvic fins situated laterally posterior to disc. First dorsal fin and second dorsal fin separated and almost equal sized, first dorsal fin situated far behind tip of the pelvic fin. Dorsal profile uniformly yellowish to greyish brown; snout region is whitish or translucent (Last et al., 2016).

Remarks: Previously, two species under the genus Glaucostegus i.e. Glaucostegus granulatus (Cuvier, 1829) and Glaucostegus thouin (Anonymous [Lacepède], 1798) were reported by Rao (2003) and Rajan et al. (2013) from Andaman and Nicobar Islands. The current observation confirmed the occurrence of $G$. typus in the region. Giant guitarfishes are caught occasionally as bycatch of artisanal and trawl fisheries in Andaman. The IUCN Red List of Threatened Species lists the status of $G$. typus as Critically Endangered (Kyne et al., 2019).

Order: Rajiformes

Family: Rajidae

Orbiraja cf. powelli (Alcock, 1898)

Indian ring Skate (Fig 2C)

Observation/materials: A female specimen $(44.5 \mathrm{~cm} \mathrm{TL})$ was caught as bycatch in a deep-sea shrimp trawl and landed at Junglighat fish landing center.

Diagnosis: $O$. cf. powelli is a medium sized skate with a rhombic disc, moderately elongated snout with firm rostral cartilage. Eyes small with incomplete rosette of orbital thorns. Dorsal profile is brown with two large pectoral ocelli prominent on the dorsal surface.

Remarks: Detailed examination and molecular analysis of
O. cf. powelli is under progress for further clarification on its taxonomic status based on the specimen collected. The color pattern and some morphometric features show clear variation from the materials identified as 0 . powelli collected from off Tuticorin, Tamil Nadu (Bineesh et al., 2016).

Order: Myliobatiformes

Family: Hexatrygonidae

Hexatrygon bickelli Heemstra \& Smith, 1980

Sixgill stingray (Fig. 2D)

Observation/materials: A single female specimen ( $68 \mathrm{~cm} \mathrm{TL})$ of Sixgill stingray, H. bickelli was caught during an exploratory survey by FORV Sagar Sampada from Nicobar Islands (Cruise 334, leg II; Image by Sumod K.S.)

Diagnosis: H. bickelli is a rare deepwater stingray characterized by triangular shaped long snout with broad base, entire body smooth, lack of denticles, flabby heart shaped disc, short tail, 1-2 caudal stings and small pelvic fins. Disc deeply concave behind eyes, apex broadly rounded and posteriorly convex. Six pair of gill slits situated on the ventral region of the head. Eyes widely separated. Dorsal profile of disc pale pinkish to reddish in color, posteriorly slight dark, snout whitish or translucent, ventrally white (Last et al., 2016).

Remarks: Several species have been described under the family based on the relative snout length and shape, however, currently all were considered as synonyms of $H$. bickelli. So far, single species under this family is known to be valid and distributed in Indo-Pacific, South Africa to Hawaii at depth ranges from 360-1120 m. Previous literature does not include the report of H. bickelli from Andaman and Nicobar waters. However, the current observation confirmed its presence in the region. The IUCN Red List of Threatened Species lists the status of $H$. bickelli as Least Concern (Mc Cormack et al., 2015).

Order: Myliobatiformes

Family: Dasyatidae

Himantura leoparda Manjaji-Matsumoto \& Last, 2008 Leopard whipray (Fig. 2E)

Observation/materials: H. leoparda was commonly observed in the local fish market/landing center of the Andaman and Nicobar Islands caught in gillnet/ hook and lines along with grouper and carangids by motorized boats. Mature male individuals having size ranges of $88-114 \mathrm{~cm} \mathrm{DW}$ and mature female with size ranges $96-122 \mathrm{~cm}$ DW were observed in the catches of trawlers operated at depth ranges 10-30 $\mathrm{m}$. Complexity in species-specific identification has led to misidentification of this species as $H$. uarnak in the landings for a long time. 


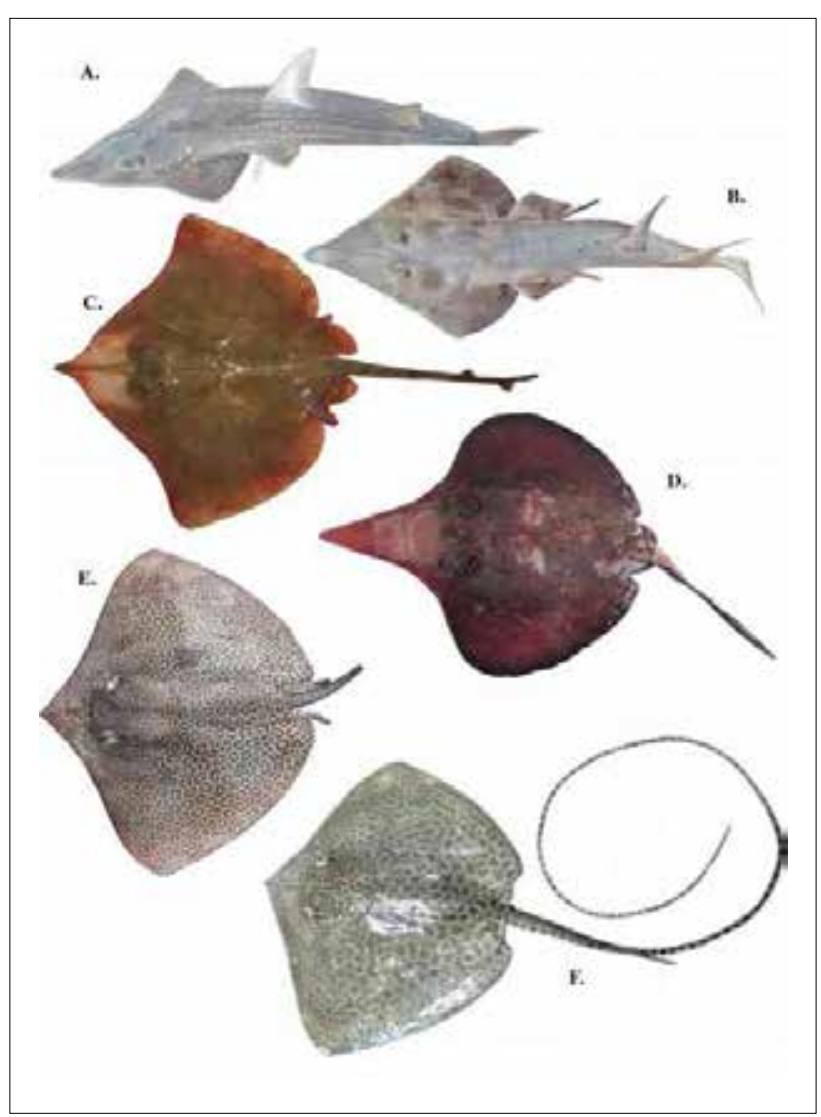

Fig. 2. R. australiae (A); G. typus (B); O. cf. powelli (C); H. bickelli (D); H. leoparda (E); H. undulata (F)

Diagnosis: $H$. leoparda is characterized by a dorsal surface with a dense pattern of dark medium-sized rings (bigger on the mid-disc than the edge). Snout broadly pointed, weakly rhombic shaped disc with skirt-shaped nasal curtain and welldeveloped band of denticles in adults, whip-like tail without skin folds (Last et al., 2016).

Remarks: Recent literature revealed that under the genus Himantura four species described and a single species i.e. Himantura uarnak (Gmelin, 1789) was recorded from Andaman and Nicobar Islands by Rao (2003). However, the present study confirmed the occurrence of $H$. leoparda in this region. It is widely distributed in Indo-West Pacific, from South Africa to eastern Australia and Japan. The IUCN Red List of Threatened Species lists the status of $H$. leoparda as Vulnerable (Rigby and Moore, 2016).

Order: Myliobatiformes

Family: Dasyatidae

Himantura undulata (Bleeker, 1852)

Honeycomb whipray (Fig 2F)

Observation/materials: $H$. undulata was observed occasionally in the landings of Andaman and Nicobar Islands. There were four mature male Individuals having size ranges of $84-120 \mathrm{~cm}$ DW and five mature female with size ranges $92-126 \mathrm{~cm}$ DW caught by gillnet/hook \& lines by motorized boat on $14^{\text {th }}$ June 2019 operated at depth ranges $10-30 \mathrm{~m}$.

Diagnosis: $H$. undulata can be differentiated from $H$. leoparda by the larger dark rings and reticulations on the dorsal surface and pearl shaped (rather than heart-shaped) thorns of the middisc (Last et al., 2016).

Remarks: Complexity in species-specific identification of genus Himantura, look like species possibly led to continued misidentification as $\mathrm{H}$. leoparda and $\mathrm{H}$. uarnak in the fishery. $\mathrm{H}$. uarnak (Gmelin, 1789) was recorded from Andaman and Nicobar Islands by Rao (2003). However, the present study confirmed the occurrence of $\mathrm{H}$. undulata in this region. It is distributed in Indo-West Pacific, from India to Java and Borneo. The IUCN Red List of Threatened Species lists the status of $H$. undulata as Vulnerable (Rigby, 2012)

Order: Myliobatiformes

Family: Dasyatidae

Neotrygon cf. caeruleopunctata Last, White and Seret, 2016 Bluespotted maskray (Fig. 3G-H)

Observation/materials: $N$. cf. caeruleopunctata was observed commonly in the local fish markets in the Andaman and Nicobar Islands. This species caught in gillnet along with carangids and grouper fishes and also by trawl catches. The size range of mature male was $19-28 \mathrm{~cm}$ DW and female was $18.5-29 \mathrm{~cm} \mathrm{DW}$.

Diagnosis: $N$. cf. caeruleopunctata is characterized by pale greenish brown dorsal surface with many small to medium sized blue ocelli (pale blue covered by darker blue outside).

Remarks: This species from the Andaman Islands was earlier reported as Neotrygon kuhlii by several authors (Rao, 2003, Rajan et al., 2012, 2013). Detailed studies on the blue spotted stingrays are needed in India to explore the actual diversity.

Order: Myliobatiformes

Family: Dasyatidae

Pastinachus ater (Macleay, 1883)

Broad cowtail ray (Fig 3J)

Observation/materials: $P$. ater was occasionally observed at Junglighat fish landing center, Port Blair caught in gillnet that targeting groupers and snappers and also caught by commercial trawler in coastal waters. The size range of male was 34-79 $\mathrm{cm}$ DW and female was 42-168 cm DW. Often misidentified as lookalike species Pastinachus sephen. 
Diagnosis: P. ateris characterized morphologically with flat denticles forming a wide band on the central disc. Band of denticles is band distinct but less dense towards outer pectoral fin. Dorsal profile uniform dark greyish brown to black; long blackish tail with welldeveloped ventral tail fold by the filament (Last et al., 2016).

Remarks: Rajan et al. (2013) previously recorded $P$. sephen from the Andaman Islands. The present study documents a new record of $P$. aterfrom the region. The distribution includes Indo-West Pacific from Madagascar to New Caledonia. The IUCN Red List of Threatened Species lists the status of $P$. ateras Least Concern (Morgan et al., 2016).

Order: Myliobatiformes

Family: Dasyatidae

Pateobatis jenkinsii (Annandale, 1909)

Jenkins' whipray (Fig. 3l)

Observation/materials: $P$. jenkinsii was commonly observed at fish landing centers around the Andaman and Nicobar Islands. This species caught in bottom set gillnet along with other rays P. fai, $H$. uarnak and $H$. undulata and also as bycatch in trawl fishery. The size range of mature male was $78-110 \mathrm{~cm}$ DW and female was 88-138 cm DW.

Diagnosis: This species is characterized by a broad rhombic disc, nasal curtain skirt-shaped, a row of enlarged thorny denticles along the mid-disc and tail. Dorsal profile yellowish brown, ventrally white; tail blackish beyond the sting in colour (Last et al., 2016).

Remarks: P. jenkinsii was mostly observed in the landings along with another commonly landed Pink whipray. Distribution pattern includes Indo-Pacific from South Africa to New Guinea, north to the Philippines. The IUCN Red List of Threatened Species list the status of $P$. jenkinsii as Vulnerable (Manjaji et al., 2016)

Order: Myliobatiformes

Family: Dasyatidae

Pateobatis fai (Jordan \& Seale, 1906)

Pink whipray (Fig. 3K)

Observation/materials: P. fai are commonly landed in Andaman and Nicobar Islands. This species caught in bottom set gillnet along with other rays $P$. jenkinsii, $H$. uarnak and $H$. undulata and also as bycatch in trawl fishery. The observed male individuals having size ranges $92-124 \mathrm{~cm}$ DW and female with size ranges 98-134 cm DW were caught by gill nets operated at depth ranges $20-50 \mathrm{~m}$.

Diagnosis: $P$. fai is a large sized ray, and is characterized by a broad rhombic disc, uniformly pinkish colour dorsally. No extended band of denticles in the dorsal disc. No bands on tail, post spine tail blackish (Last et al., 2016).

Remarks: P. fai is a common species in the fishery landing. The IUCN Red List of Threatened Species list the status of $P$. fai as Vulnerable (Manjaji et al., 2016).

Order: Myliobatiformes

Family: Dasyatidae

Urogymnus asperrimus (Bloch \& Schneider, 1801)

Porcupine whipray (Fig 3L)

Observation/materials: The porcupine whipray is a reefassociated ray, uncommon in the fisheries. One mature male and a female measuring 76 and $90 \mathrm{~cm}$ DW respectively were accidently caught and landed at Junglighat landing center on 21.02.2016 and 17.03.2018.

Diagnosis: This species is characterized by a sub-circular disc with extremely rough and prickly dorsal surface. Tail slender, almost equal to disc length and cylindrical in cross section and tapering to the end of the tail, makes this species very distinct from all other stingrays (Last et al., 2016).

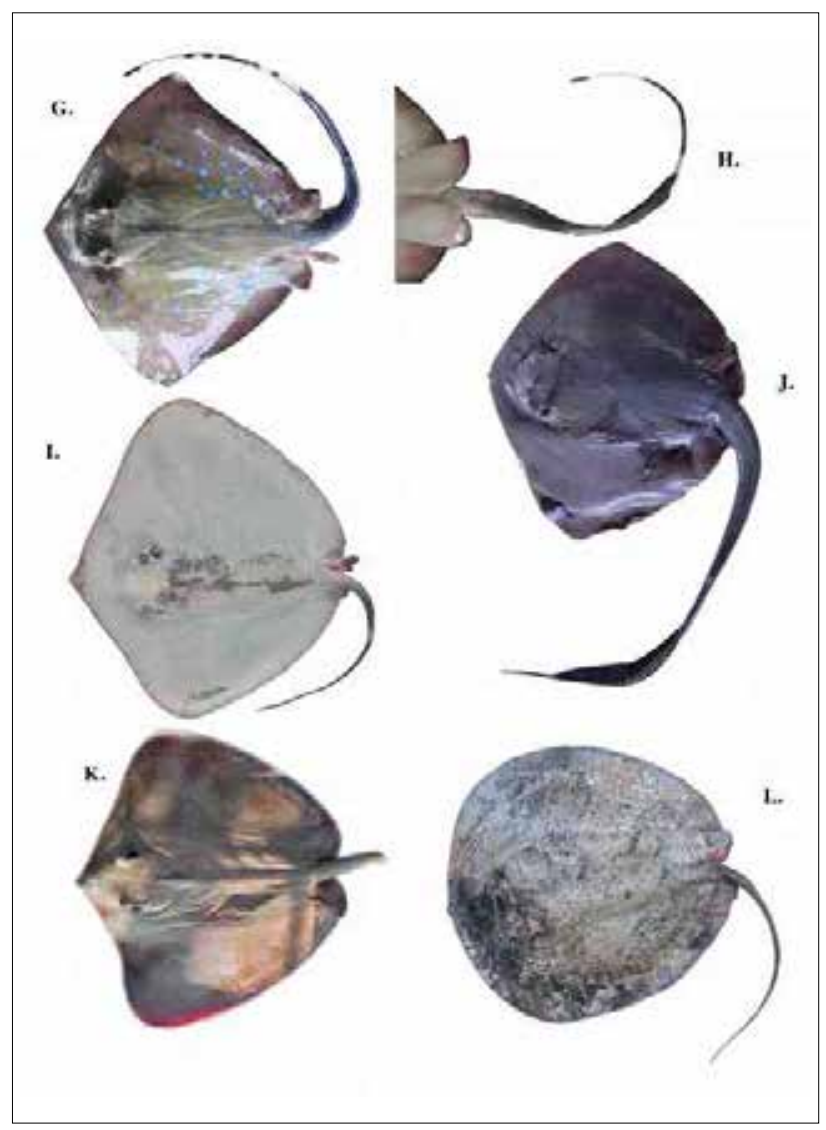

Fig. 3. N. cf. caeruleopunctata (G-H); P. jenkinsii (I); P. ater (J); P. fai (K); U. asperrimus (L) 
Remarks: This species was protected under the Indian Wildlife (Protection) Act 1972, Schedule-I-Part-II (A) - Fishes. There are no previous reports of $U$. asperrimus from the Andaman and Nicobar region (Rao, 2003; Rajan et al., 2012, 2013). Hence, the current report is the first time from this region. The species is reported to have a widespread distribution in the Indo-West Pacific and Eastern Atlantic. The IUCN Red List of Threatened Species lists the status of $U$. asperrimus as Vulnerable (Chin and Compagno, 2016).

Order: Myliobatiformes

Family: Myliobatidae

Aetomylaeus vespertilio (Bleeker, 1852)

Ornate eagle ray (Fig. 40)

Observation/materials: $A$. vespertilio was observed at Junglighat fish landing center twice, two female specimens measuring 160 and $190 \mathrm{~cm}$ (DW) were landed on $16^{\text {th }}$ January 2018 and $2^{\text {nd }}$ October 2018 respectively.

Diagnosis: This species is characterized by its brown to bluish grey dorsal surface with black lines arranged transversely on anterior half of disc and open network on the posterior half (Last et al., 2016).

Remarks: $A$. vespertilio is a rare species known from Indo-West Pacific, with patchy distribution in the Red Sea, Mozambique, Northern Australia and Southern China. This species has been reported in fish landings at Kochi, south west India by Bineesh et al. (2014). A single species, Aetomylaeus nichofii under the genus Aetomylaeus was reported in the checklist of fishes from Andaman and Nicobar Islands (Rajan et al., 2013). The occurrence of $A$. vespertilio is an additional record for this region. Due to high fishing pressure level in inshore regions, $A$. vespertilio has been assessed as Endangered by the IUCN Red List of Threatened Species list (White and Kyne, 2016).

Order: Myliobatiformes

Family: Aetobatidae

Aetobatus flagellum (Bloch \& Schneider, 1801)

Longheaded eagle ray (Fig. 4M-N)

Observation/materials: A. flagellum was occasionally observed in the landing center of the Andaman and Nicobar Islands. Four mature male Individuals having size ranges $64-84 \mathrm{~cm} \mathrm{DW}$ and six mature females with size ranges $76-88 \mathrm{~cm}$ DW were caught by gill nets operated at depth ranges $20-50 \mathrm{~m}$.

Diagnosis: Long rostral lobe and narrowly pointed, disc very broad and short. Nasal curtain large, deeply notched centrally and with a curtain-like fringe. Very long tail, 1.2-1.8 times DW (Last et al., 2016).
Remarks: Though the species is mentioned to have no spots in dorsal, some, materials identified as $A$. flagellum had spots in the posterior ends, over the pelvic and both sides of tail at tail origin. A. flagellum has been assessed as Endangered in the IUCN Red List of Threatened Species (White, 2006).

Order: Myliobatiformes

Family: Mobulidae

Mobula kuhlii (Valenciennes, 1841)

Kuhl's devilray (Fig. 3Q)

Observation/materials: Two mature females with size ranges $178 \mathrm{~cm} \mathrm{DW}$ and $182 \mathrm{~cm}$ DW respectively were landed on $24^{\text {th }}$ January 2018 and $12^{\text {th }}$ February 2018 at Junglighat landing center.

Diagnosis: Devil rays are medium to very large in size with a rhomboidal, wing-like disc which is broader than long. Dorsal profile black to greyish brown; dorsal fin plain; ventral surface is white (Last et al., 2016).

Remarks: Total 3 species under the genus Mobula were reported from Andaman and Nicobar Islands i.e. Mobula birostris, Mobula

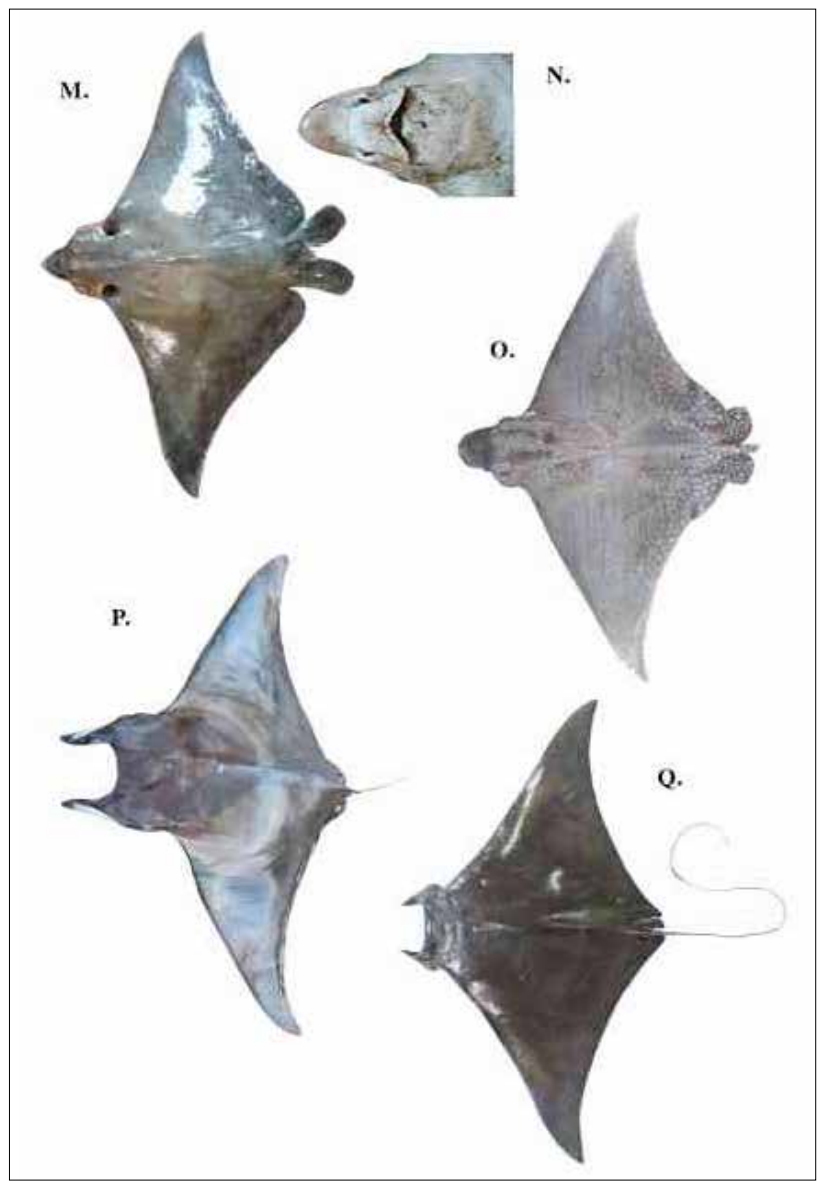

Fig. 4. A. flagellum (M-N); A. vespertilio (O); M. tarapacana (P); M. kuhlii (Q) 
mobular and Mobula thurstoni (Rao, 2003; Rajan et al., 2012; Shirke et al., 2017). M. kuhlii was hitherto not known from the region. Thus, this is a confirmed first record of the species from this region. Distribution records for this species are known from Indo-West Pacific, from South Africa to eastern Australia. The IUCN Red List of Threatened Species list the status of $M$. kuhlii as Data Deficient (Bizzarro et al., 2009).

Order: Myliobatiformes

Family: Mobulidae

Mobula tarapacana (Philippi, 1892)

Chilean devilray (Fig. 3P)

Observation/materials: The Chilean Devilray has uncommon, patchy distribution landed at Junglighat landing center on 21.02.2016 and 17.03.2018. One mature male $(255 \mathrm{~cm} \mathrm{DW})$ and a female $(276 \mathrm{~cm} \mathrm{DW})$ were observed.

Diagnosis: This species is medium sized with broad, subterminal mouth and elongated disc. M. tarapacana can be distinguished from other mobulids by its long and strongly falcate pectoral fin and strong bony ridge on the dorsal mid-line. Dorsal profile uniformly greyish in color (Last et al., 2016).

Remarks: M. tarapacana was hitherto not reported from the region. Thus, this is the first record of the species from the region. This species have patchy distribution probably circumglobal in warm seas. The IUCN Red List of Threatened Species list the status of M. tarapacana as Endangered (Marshall et al., 2019).

Akhilesh et al. (2014) indicated that certain ecosystems in Indian waters which are poorly explored for elasmobranch faunal diversity require more scientific exploration and investigations, as several unrecognized species probably occur in these areas and many species are known with misapplied names. DNA barcoding study on elasmobranchs from the commercial fishery of mainland India indicated high diversity and suggested several possible new species/records for India (Bineesh et al., 2016).

Species diversity of batoids in Andaman and Nicobar has been poorly studied (Kumar et al., 2018). The present study revealed new regional records of 15 batoids i.e. 2 wedgefishes, 1 skate and 12 rays. The diversity of elasmobranchs in the landings from this region is higher than known or expected. Earlier works on batoids in the region do not include the species reported in the recent study (Rao 2003; Akhilesh et al., 2009; Rajan et al., 2012, 2013; Devi and Kumaralingam 2014; Vinu et al., 2017; Shirke et. al., 2017; Pradeep et al., 2018). Herewith, we report new distributional records of $R$. australiae, $G$. typus, $O$. cf. powelli, $H$. bickelli, H. leoparda, H. undulata, N. cf. caeruleopunctata, $P$. ater, . jenkinsii, P. fai, $U$. asperrimus, $A$. vespertilio, A. flagellum, M. kuhlii and M. tarapacana from the Andaman Islands. Species reported here as first-time reports from the region are common or occasional in the fishery landings. The absence of dedicated fisheries monitoring programs could have hindered the diversity studies on elasmobranchs in the past few decades. More detailed studies are required to understand the diversity of batoids in the region for better planning and management.

\section{Acknowledgements}

We express our sincere thanks to the Director, Zoological Survey of India (ZSI) for the support and facilities provided during the study. Ravi Ranjan Kumar and S. Venu acknowledge the authority of Pondicherry University for the support and are also thankful to Sumod K. S, (CMLRE) for providing the image of Hexatrygon bickelli. Authors express their sincere thanks to the fishermen and boat owners for the support during landing center/market survey and sample collections.

\section{References}

Akhilesh, K. V., K. K. Bineesh, A. Gopalakrishnan, J. K. Jena, V. S. Basheer and N. G. K. Pillai. 2014. Checklist of Chondrichthyans in Indian waters. J. Mar. Biol. Ass. India, 56(1): 109- 120

Akhilesh, K. V., M. Hashim, U. Ganga, N. G. K. Pillai and M. Sebastine. 2009. Morphometric characteristics of deepwater stingray Plesiobatis daviesi (Wallace, 1967) collected from the Andaman Sea. J. Mar. Biol. Ass. India, 51(2): 246-249.

Bineesh, K. K., A. Gopalakrishnan, K. V. Akhilesh, K. A. Sajeela, E. M. Abdussamad, N. G. K. Pillai, V. S. Basheer, J. K. Jena and R. D. Ward. 2016. DNA barcoding reveals species composition of sharks and rays in the Indian commercial fishery. Mitochondrial DNA, Part A, 28(4): 458-472.

Bineesh, K. K., K. V. Akhilesh, K. A. Sajeela, E. M. Abdussamad, A. Gopalakrishnan, V. S. Basheer and J. K. Jena. 2014. DNA Barcoding Confirms the Occurrence Rare Elasmobranchs in the Arabian Sea of Indian EEZ. Middle-East J. Sci. Res., 19(9): 1266-1271

Bizzarro, J., W. Smith, W. T. White and S. V. Valenti. 2009. Mobula kuhlii. The IUCN Red List of Threatened Species 2009: e.T161439A5424139.

Chin, A. and L. J. V. Compagno. 2016. Urogymnus asperrimus. The IUCN Red List of Threatened Species 2016: e.T39413A68648645. http://dx.doi.org/10.2305/ IUCN.UK.2016-1.RLTS.T39413A68648645.en.

Devi, K. and S. Kumaralingam. 2014. First report of whitetail stingray (Himantura granulata) from Andaman Islands. J. And. Sci. Ass., 19(1): 75-77.

Kizhakudan, S. J., P. U. Zacharia, S. Thomas, E. Vivekanandan and M. Muktha. 2015. Guidance on National Plan of Action for Sharks in India. CMFRI Marine Fisheries Policy Series-2, 1-102.

Kumar, R. R., S. Venu, K. K. Bineesh and V. S. Basheer. 2016. New biogeographic data and DNA barcodes for the Indian swellshark, Cephaloscyllium silasi (Talwar, 1974) (Elasmobranchii: Carcharhiniformes: Scyliorhinidae), from Andaman Waters. Acta Ichthyol. et Pisc., 46(2): 131-135.

Kumar, R. R., S. Venu, K. V. Akhilesh, K. K. Bineesh and P. T. Rajan. 2018. First report of four deep-sea chondrichthyans (Elasmobranchii and Holocephali) from Andaman waters, India with an updated checklist from the region. Acta Ichthyol. et. Piscat., 48(3): 289-301.

Kumar, R. R., S. Venu and K. V. Akhilesh. 2015. First report of magnificent finback catshark Proscyllium magnificum, Last and Vongpanich, 2004 (Proscyllidae: Carcharhiniformes) from Bay of Bengal, Indian EEZ. World J. Fish and Mar. Sci., 7(6): 479-481

Kyne, P. M., C. L. Rigby, Dharmadi and R. W. Jabado. 2019. Rhynchobatus australiae. The IUCN Red List of Threatened Species 2019: e.T41853A68643043.

Kyne, P. M., C. L. Rigby, Dharmadi, A. N. Gutteridge and R. W. Jabado. 2019. Glaucostegus typus. The IUCN Red List of Threatened Species 2019: e. T104061138A68623995.

Last, P. R., W. T. White, M. R.de Carvalho, B. Séret, F. W. Stehmannand and G. J. P. Naylor. 2016. Rays of the world. Cornell Uni. Press, Ithaca, NY, USA.

Manjaji, M., B. M. Fahmi, W. T. White and A. N. Gutteridge. 2016. Pateobatis fai. The IUCN Red List of Threatened Species 2016: e.T161615A104219816.

Manjaji, M., B. M. Fahmi and W. T. White. 2016. Pateobatis jenkinsii. The IUCN Red List of Threatened Species 2016: e.T161744A104229717. 
Marshall, A., R. Barreto, J. S. Bigman, J. Carlson, D. Fernando, S. Fordham, M.P. Francis, K. Herman, R. W. Jabado, K.M. Liu, S. A. Pardo, C. L. Rigby, E. Romanov and R. H. L. Walls. 2019. Mobula tarapacana. The IUCN Red List of Threatened Species 2019: e.T60199A124451161. https://dx.doi.org/10.2305/IUCN.UK.2019-3.RLTS. T60199A124451161.en. Downloaded on 26 May 2020.

McCormack, C., Y. Wang, H. Fahmi Ishihara, B. M. Manjaji Matsumoto, E. Capuli and A. Orlov. 2015. Hexatrygon bickelli. The IUCN Red List of Threatened Species 2015: e.T161674A68626659.

Morgan, D.L., W.T. White and B. M. Manjaji Matsumoto. 2016. Pastinachus ater. The IUCN Red List of Threatened Species 2016: e.T70682232A70708697. https:// dx.doi.org/10.2305/IUCN.UK.2016-1.RLTS.T70682232A70708697.en. Downloaded on 26 May 2020

Pradeep, H. D., S. S. Shirke, M. Nashad and M. D. Sukham. 2017. A first record of the smallfin gulper shark Centrophorus moluccensis Bleeker, 1860 (Chondrichthyes: Squaliformes: Centrophoridae) from the Andaman and Nicobar waters, Indian EEZ. J. Threat. Taxa, 9(11): 10899-10903.

Pradeep, H. D., S. S. Swapnil, S. Ramachandran and S. K. Pattnayak. 2016. Report of the crocodile shark Pseudocarcharias kamoharai (Matsubara, 1936) from deep waters of the Andaman Sea. Mar. Biodiv., 47(2): 535-538.

Pradeep, H. D., S. S. Swapnil, M. Nashad, S. Venu, R. R. Kumar, G. Sumitha, D. S. Monalisha and M. K. Farejiya. 2018. First record and DNA barcoding of Oman cownose ray, Rhinoptera jayakari Boulenger, 1895 from Andaman Sea, India. Zoosystema, 40(4): 67-74.

Rajan, P. T., C. R. Sreeraj and T. Immanuel. 2013. Fishes of Andaman and Nicobar Islands: A checklist. J. Andaman Sci. Ass., 18(1): 47-87.
Rajan, P. T., C. R. Sreeraj and K. Venkataraman. 2012. Diversity and abundance of chondrichthyan fishes in Andaman and Nicobar Islands. In: Venkataraman, K., C. Raghunathan and C. Sivaperuman, (Eds.) Ecology of faunal communities on the Andaman and Nicobar Islands. Springer-Verlag Berlin Heidelberg, 117-126 p.

Rao, D. V. 2003. Guide to reef fishes of Andaman and Nicobar Islands. Zoological Survey of India, Kolkata, India.

Rigby, C. 2012. Himantura undulata. The IUCN Red List of Threatened Species 2012: e.T161621A14793852.

Rigby, C. A. and D. R. Moore. 2016. Himantura leoparda. The IUCN Red List of Threatened Species 2016: e.T195456A68628645.

Shirke, S. S., M. Nashad, M. D. Sukham and H. D. Pradeep. 2017. A first record of the bentfin devil ray Mobula thurstoni (Lloyd, 1908) (Myliobatiformes: Mobulidae) from the Indian EEZ of the Andaman Sea. J. Threat. Taxa, 9(12): 11074-11080.

Tyabji, Z., R. W. Jabado and D. Sutaria. 2018. New records of sharks (Elasmobranchii) from the Andaman and Nicobar Archipelago in India with notes on current checklists. Biodiv. Data J. 6: e28593.

Vinu, J., M. P. Rajeeshkumar, U. V. Parmeswaran, K. S. Sumod, K. V. Akhilesh, H. Manjebrayakath and V. N. Sanjeevan. 2017. Redescription and sexual dimorphism of Andaman leg-skate Cruriraja andamanica (Chondrichthyes: Rajiformes) with comments on the zoogeography of the genus Cruriraja. J. Fish Biol., 91(2): 587602.

White, W. T. and P. M. Kyne. 2016. Aetomylaeus vespertilio. The IUCN Red List of Threatened Species 2016: e.T60121A68607665.

White, W. T. 2006. Aetobatus flagellum. The IUCN Red List of Threatened Species 2006: e.T60119A12306888. 